\title{
DINAMIKA PERBEDAAN PENDAPAT TERKAIT KEWARISAN ANAK KETIKA FORMULASI KOMPILASI HUKUM ISLAM
}

\author{
Muhammad Fadhlan Is \\ Dosen Prodi Hukum Keluarga STAIN Mandailing Natal \\ Email : fadhlan_102585@yahoo.com
}

\begin{abstract}
An opinion differencein the stipulation of Islamic Law is not a new thing. It already existed even when the Prophet was still alive. Likewise, during the KHI formulation, it was clear that there was a dynamic of opinion differenceamong Islamic Law, Customary Law and Civil Law (Burgerlijk Wetboek) which were intersected in influencing the stipulation of the Islamic Lawin the country. There are many factorsthat lead to the dynamics of different opinions; among others is the existence of Civil Law products (Burgerlijk Wetboek) which had been applied before KHI. This colonial Law is what influences the national lawyers' pattern of thinkingin determining Islamic law in KHI. The results of the study show the fact that the formulation of KHI through a structural approach is top down from the central government, but still involves the role of the ulama, scholars and practitioners of Islamic law. KHI material absorbs fiqh that is familiar in the country. The dynamics of differences of opinion are found in three patterns of Islamic Law thought that emerged at that time. First, the literalisasi group, which is a group that opposes thoughts that violate the nash qat'i. Secondly, the group is assimilative, this group tries to find a new interpretation in understanding nash qat'i. The three groups are Harmonized, Characteristics of this group may be out of zahir nash, if judging there are provisions that can be an alternative, inheritance is included in the category of mu'amalat worship which must be open to accepting changes by considering the interests and eliminating the narrowness in society.
\end{abstract}

\begin{abstract}
ABSTRAK
Perbedaan Pendapat dalam penetapan Hukum Islam bukanlah suatu hal yang baru, bahkan sudah terjadi disaat Rasulullah masih hidup. Begitu juga ketika formulasi KHI, terlihat jelas adanya dinamika perbedaan pendapat antara Hukum Islam, Hukum Adat dan Hukum Perdata (Burgerlijk Wetboek) yang bersaing dalam mempengaruhi penetapan ketentuan Kompilasi Hukum Islam di Tanah air. Banyak faktor yang menyebabkan dinamika perbedan pendapat dalam formulasi KHI. Hasil penelitian menunjukkan fakta terkait dinamika perbedaan pendapat terjadi dalam formulasi KHI diaktori tiga corak pemikiran Hukum Islam yang muncul di waktu itu, Pertama, kelompok bercorak tekstul, yaitu kelompok yang menentang pemikiran yang melanggar nas $\}$ qat\}' $i>$. Kedua, kelompok bercorak asimilatif, kelompok ini mencoba mencari tafsir baru dalam memahami nas\} qat\}'i. Ketiga kelompok bercorak Harmonisasi, Ciri dari kelompok ini mengusulkan revisi beberapa hukum yang digagas oleh dua kelompok sebelumnya, bagi kelompok ini kewarisan termasuk kategori ibadah mu'amalat yang mesti terbuka menerima pembaharuan.
\end{abstract}

Kata kunci: Dinamika, Perbedaan Pendapat, Formulasi, Kompilasi Hukum Islam,Waris, Hibah dan Wasiat.

\section{A. Pendahuluan}

Sejarah mencatat keberhasilan

dalam usaha formulasi KHI banyak dibayang-bayangi oleh persaingan dan pertarungan antara beberapa pemikiran hukum Islam, terlebih lagi saat itu mayoritas Muslim Indonesia menganut mazhab Sya>fi'iyah (Azhar, 2016). Terkait tentang hukum waris ketika pertengahan dekade 80-an, Munawir Sjadzali yang ketika itu menjabat sebagai menteri agama RI, pernah melontarkan ide agar dalam pembagian waris umat Islam Indonesia memberikan bagian yang sama terhadap anak laki-laki dan perempuan. Munawir Sjadzali mengemukakan bahwa al-Qur'an 
menganut nasakh (pembatalan), bagian 2:1 bisa dinasakh atau dibatalkan hukumnya, hal ini didasarkan pada budaya dan adat Arab setempat. Dahulu pada masa sebelum Islam, wanita sama sekali tidak mendapatkan warisan. Setelah Islam datang, wanita diberi bagian warisan meskipun hanya setengah (Sjadzali, 1993)

Amir Syarifuddin, menjelaskan "KHI secara umum dipandang sebagai fikih khas Indonesia yang berbeda dengan negara Islam lainnya, Munculnya KHI di Indonesia sebagai hasil pemikiran Hukum Islam Indonesia yang diwakili oleh para ulama, pakar hukum Islam dan cendekiawan se-Indonesia dengan melakukan beberapa tahapan-tahapan. Namun disebabkan adanya perbedaan di kalangan kelompok atau perorangan di kalangan ulama dalam paradigma metodologi dan metode ijtihad dalam memahami teks al-Qur'an dan Sunah tentang hukum kewarisan Islam yang baru ini, melahirkan dinamika perbedaan pendapat dan bahkan penolakan ketika diformulasikannya Kompilasi Hukum Islam waktu itu (Amir Syarifuddin, 2017)

Yahya Harahap, salah seorang perumus KHI dalam tulisannya menyatakan :

"Jangan mimpi seolah-olah KHI sudah final dan sempurna. Jangan tergoda oleh bayang-bayang kepalsuan yang menganggap KHI sebagai karya sejarah yang monumental dan agung, keliru sekali impian dan hayalan seperti itu. Yang benar, terima dan menyadari KHI dengan segala kekurangan dan ketidaksempurnaan. Pengkaji dan perumusnya adalah manusia biasa dengan segala sifat epemeral yang melekat pada dirinya. Sudah pasti KHI banyak sekali mengandung kelemahan-kelemahan dan ketidak sempurnaan" (Harahap, 1999)

Berdasarkan pemaparan di atas, penulis akan mengungkapkan bagaimana dinamika perbedaan pendapat dalam formulasi kewarisan anak dalam Kompilasi Hukum Islam dan bagaimana corak pemikiran hukum Islam yang terjadi ketika itu baik dari segi materi, matode ijtihad dan istinbat hukumnya.

\section{B. Kajian Literatur}

Di antara tulisan, buku dan karya ilmiyah lainnya yang relevan dengan kajian ini, penulis temukan diantaranya adalah:

Penelitian disertasi dari Habiburrahman (2014), dimana ia menggugat dasar kehujjahan beberapa pasal-pasal waris KHI yang tidak diatur dalam al-Qur'an, Hadis dan kitab-kitab fikih ulama mujtahid terdahulu, dasar pertimbangan hukum serta tinjauan teoriteori hukum terhadap pasal-pasal ketentuan dari pasal-pasal tersebut justru 
dianggap bertentangan dengan asas ijbarri dalam hukum kewarisan Islam (Habiburrahman, 2011)

Penelitian disertasi yang dilakukan Suparman Usman (2012) yang berjudul “ Hukum Islam Dalam Hukum Positif di Indonesia, Studi Kritis Hukum Kewarisan Menurut KHI di Indonesia dan pelaksanaannya di Pengadilan Agama. Penelitian beliau ini membahas tentang sejauh mana pengaturan materi hukum kewarisan Islam menurut KHI sebagai hukum positif di Indonesia.

Penelitian disertasi oleh Minhajul Falah yang meneliti aturan kewarisan yang ditawarkan KHI dan dibandingkan dengan aturan kewarisan dalam fikih klasik. Dimana ia menemukan bahwa kerancuan dan ketidak relevanan satu aturan dengan aturan kewarisan lainnya dan kekacauan dalam penerapannya (Falah, 1993)

Penelitian disertasi IAIN Imam Bonjol Padang, yang ditulis oleh Elfia (2016), dengan judul “ Kebijakan Hukum Dalam Penyelesaian Warisan Menurut Hukum Kewarisan Islam. penelitian ini membahas tentang bagaimana kebijakan hukum dalam pembagian warisan secara takharruj menurut ulama Hanafiyah dan selain ulama Hanafiyah.

Berbeda dengan fokus penelitianpenelitian sebelumnya, dalam penelitian penulis akan membahas tentang dinamika perbedaan pendapat dalam formulasi KHI tentang hukum waris, hibah dan wasiat, dilihat dari sisi materi ijtihad, metode ijtihad dan Istinbat hukum.

\section{Metode Penelitian}

Penelitian ini merupakan field research (penelitian lapangan) dengan menggunakan pendekatan kualitatif deskriptif. Sumber data yang digunakan dalam penelitian ini adalah sumber data primer dan data sumber data sekunder. diperoleh dari wawancara langsung dilakukan terhadap informan seperti para perumus langsung yang terlibat dalam formulasi Kompilasi Hukum Islam, juga beberpa pakar hukum Islam yang dipandang memahami masalah yang diteliti. Adapun data sekunder untuk penelitian ini diambil dari buku yang terkait dan beberapa jurnal hasil penelitian seperti Mimbar Hukum yang pernah terbit secara berkala diawal-awal lahirnya KHI. Adapun teknik analisis data yang akan dilakukan peneliti yaitu reduksi data, penyajian data, melakukan verifikasi dan menarik kesimpulan.

\section{Hasil Dan Analisis Penulis}

1. Dinamika perbedaan pendapat ketika formulasi terkait kewarisan anak ketika formulasi Kompilasi Hukum Islam

Munculnya perbedaan pendapat yang paling tajam dikalangan ulama dalam 
merancang hukum kewarisan KHI adalah ketika wacana Menteri Agama Munawir Sjadzali dan Tim Perumus KHI yang ingin menyamaratakan porsi waris anak lelaki dengan anak perempuan menjadi 1:l. Munawir Sjazali (Sjadzali, n.d.) dalam berbagai forum dan seminar terkait Hukum Islam, sering melontarkan gagasannya untuk memberikan porsi waris yang sama antara anak laki-laki dan perempuan, gagasannya tersebut memancing polemik dan perbedaan pendapat diberbagai kalangan, ada yang mendukung dan tidak sedikit yang menentang keras gagasanya tersebut (Sjadzali, 1986)

Untuk menguatkan pendapatnya itu Munawir Sadzali memberikan beberapa argumentasi, diantaranya: Pertama, melihat "realita" kehidupan dimasyarakat Indonesia, pembedaan waris antara anak laki-laki dengan anak perempuan 2:1 dalam surat An-Nisa ayat 11 sangat tidak adil dan merugikan anak perempuan, beliau mencoba menawarkan perlunya melakukan penafsiran ulang dengan memberikan porsi yang sama banyak diantara anak laki-laki dan anak perempuan. Kedua, jika dinyatakan pembagian anak laki-laki dengan anak perempuan 2:1 adalah bersumber dari dalil Qath'i, beliau menjawab bahwa dalam al-Qur'an dan Hadis Nabi terdapat naskh. Dalam kitab suci terdapat ayat-ayat yang berisikan pergeseran atau bahkan pembatalan terhadap hukum-hukum atau petunjuk yang diturunkan sebelumnya. Ketiga, konsensus para ulama bahwa Hukum Islam terbagi atas dua kategori, yaitu Ibadah mah\}dah dan Ibadah muamalah. Dalam ibadah mu'amalat ini lebih luas ruang gerak untuk penalaran intelektual dengan kepentingan masyarakat sebagai dasar pertimbangan atau tolak ukurnya, seperi hukum kewarisan yang termasuk dalam kategori hukum kedua ini. Keempat, ketika mesti mencontoh bagaimana ketauladanan dari Umar Bin Khattab, yang telah berani mengeluarkan kebijakan dalam bidang hukum yang tidak sepenuhnya sesuai dengan bunyi ayat-ayat al-Qur'an. Kasus yang paling terkenal adalah permasalahan pembagian rampasan perang yang keluar dari petunjuk al-Qur'an, surat al-Anfal ayat 41 (F.Mas'udi, 1988)

Terkait gagasan Munawir Sjazali dalam bukunya "Aktualisasi Ajaran Islam" telah banyak menimbulkan perbedaan pendapat dari beberapa ulama dan cendikiawan muslim yang hidup dimasa itu. Pada tahun 1987 Pustaka Panjimas menerbitkan sebuah kumpulan tulisan yang disadur dari forum pendapat terkait beberapa tanggapan dan kritikan pemikiran Munawir Sajzali ini. Kumpulan tulisan ini diberi judul "Polemik Reaktualisasi Ajaran Islam”. Sebagaimana kasus-kasus sebelumnya, ketika ada tawaran pemikiran Islam yang berbeda 
dengan pemahaman umum masyarakat yang sudah mapan selalu menuai kontroversi, ada yang mendukung dan ada yang menolak, dan ada juga yang mendukung dengan revisi terkait porsi warisan anak ini:

a. Kelompok yang menolak Tawaran hak waris untuk Anak Laki-Laki dan Perempuan Menjadi 1:1 Dan Argumentasinya.

1) Rifyal Ka'bah

Menanggapi tawaran pemikiran Munawir yang menyatakan perasaan Munawwir kurang enak menerima keadilan ilahi yang menetapkan pembagian warisan anak laki-laki dua kali lipat dari pembagian anak perempuan". Rifyal menyatakan bahwa Munawir terpengaruh oleh konsep keadilan Liberal. Menurut Rifyal, manusia adalah hamba Allah, dipandang sama dihadapan Allah, tetapi fungsi dan kewajiban mereka berbeda. Laki-laki sebagian suami dan ayah, posisinya dinaikkan sebagai kepala keluarga yang harus bertanggungjawab dalam nafkah lahir dan batin kepada keluarganya, dan wanita sebagai ibu dan istri bertugas mengurus kedalam keluarga dengan mendidik anak dan memberikan kasih sayang kepada seluruh anggota keluarga. Dalam hal ini wanita tidak dibebani tanggung jawab keuangan(Darokah, 1987)
Mengenai pembatalan hukum dengan nasakh yang telah ditegaskan oleh teks al-Qur'an dan Sunnah adalah hak khusus pembuat syari'at (Allah dan Rasul). Sekarang pembatalan tersebut tidak dapat dilakukan lagi karena wahyu telah terhenti dan rasul telah tiada, sementara itu, nalar manusia yang disebut ra'yu dapat digunakan sebagai sumber hukum. Praktek nasakh dalam kasus ini dapat berimbas kepada hak-hak kesaksian, hak talak, keluarnya rumah tanpa muhrim dan lain sebagainya yang sudah menjadi ketentuan baku dalam syariat Islam.

2) Ali Yafie

Menurutnya naskh hukum dalam ayat yang qat'i al-Qur'an dan Sunnah, maka hal ini tidak pada tempatnya lagi, karena perubahan hukum melalui jalur naskh berakhir sejak wafatnya penerima wahyu yaitu Rasulullah Saw. Karena masalah waris menurutnya termasuk kategori hukum-hukum keluarga yang dinilai sama dengan solat, zakat,puasa dan hukum semuanya ini dipandang sesuatu yang tauqisfiyah (berdasarkan wahyu dan kepatuhan) sekalipun ada kalanya disertai dengan penjelasan hikmahnya. Jenis hukum seperti ini tidak menerima lagi perubahan. Dalam analisis Ali Yafie, hal ini termasuk kedalam kategori "Urf Farsid", terkait dengan warisan anak perempuan dibenarkan sama besarnya dengan yang diberikan kepada anak laki-laki, maka 
menurutnya hal ini tidak boleh dilakukan karena bertentangan dengan hukum syari'at Islam dan termasuk kepada bentuk 'urf farsid yang tidak dapat dipakai dalam melahirkan hukum syara'.

3) Aminullah HM.

Persoalan yang ditulis oleh Munawir, yang menyatakan, "saya kok tidak "sreg" kalau saya meninggal nanti tiga anak laki-laki saya yang sudah saya ongkosi mahal itu masih akan menerima dua kali lebih besar dari pada apa yang diterima oleh anak perempuan-perempuan saya". Aminullah menjelaskan bahwa logika yang digunakan oleh Munawwir adalah "tidak matang". Pasalnya yang menjadi ukuran besar kecilnya konsumsi kebutuhan hidup dilihat dari yang sekarang dijalani, tetapi, lebih jauh yang dilihat adalah posisi tanggung jawab, yang jelas berbeda antara antara laki-laki dan perempuan.

b. Kalangan Pendukung Penuh Pemikiran Munawir Sadzali dalam Menyamakan Porsi Waris Anak 1:1.

1) Masdar F. Mas'udi

Beliau adalah Seorang cendikiawan muda NU, ketika Masdar mendengar langsung gagasan dari Munawir dalam sebuah acara wisudah di IAIN Syarif Hidayatullah tahun 1987, membuat dirinya terbawa ikut menerima gagasan Munawir, yang menurutnya Munawir berhasil memunculkan opini ditengah-tengah peserta seminar tersebut bahwa sejumlah ayat al-Qur'an sudah tidak relevan dengan rasa keadilan yang berkembang dimasyarakat, diantara yang paling mencolok adalah perbedaan porsi 2:1 bagi anak laki-laki dan perempuan (Sjadzali, 1986)

Terkait polemik pemikiran Munawir dalam permasalahan porsi waris anak laki-laki dan perempuan dalam pemikiran Masdar F. Mas'udi menyampaikan beberapa pokok-pokok pikiran diantaranya (F.Mas'udi, 1988) Pertama, dengan memandang ayat-ayat alQur'an tetap sebagai ayat yang berarti tanda dan simbol dari ide-ide universal yang demi fitrah telah diakui oleh segenap manusia semata-mata karena dia manusia. Maka terobosan atau "modifikasi"dalam pikiran Munawir secara teoritis adalah bisa, dan dalam kondisi tertentu malah tak terelakkan. Kedua, Kategori qat\}'i dan złanni>, sebagai istilah tidak terdapat baik dalam al-Qur'an maupun Hadis Nabi. Istilah ini adalah produk ulama fikih, yang mana istilah ini diciptakan untuk membebaskan diri dari kontroversi yang cukup seru seputar "mutasyabbihast. Ketiga, syariat yang tersurat dalam 2:1 antara pewaris pria dan wanita bisa saja diubah dan di modifikasi. Menurut hemat Masdar bahwa semangat ayat itu lebih kepada keinginan untuk menggaris bawahi suatu prinsip (Sunatullash), bahwa tuntutan tanggung jawab laki-laki dalam kehidupan 
keluarga adalah lebih berat dari pada yang harus dipikul oleh wanita. Tapi kondisi tersebut bisa berubah sesuai dengan kondisi sosiologi dan budaya suatu tempat (F.Mas'udi, 1988)

2) M. Yahya Harahap

Sebagai salah seorang Hakim Agung dimasa itu, menanggapi pemikiran Munawir, beliau menjelaskan bahwa penggunaan asas qat\}' i> surat an-Nissa ayat 11 sebagai alasan menolak aktualisasi Ajaran Islam perlu ditalaah ulang. Penulis tidak mengatakan asas ini di buang. Malahan kita patut bangga atas kemampuan para mujtahid besar, menyusun sistem usul fiqih sebagai metode berfikir menentukan cara-cara menafsir dan merumus syariat. Namun sebaliknya, jika asas qathi kita paksakan dalam bidang muamalah, akan menamatkan kita sebagai "khaira ummah" (sebagai umat teladan). Seperti penolakan KB yang ddasari dari nash yang dinilai qathi (Harahap, 1999)

Menurut M. Yahya Harahap dalam memahami kalimat "farìd\}atan minalla $h$ " menjelaskan larangan untuk menghapuskan hak dan kedudukan anak perempuan mewarisi harta peninggalan orang tuanya seperti yang terjadi dimasa jahiliyah. Allah telah menetapkan batas minimum yang mesti diberikan kepada anak perempuan yakni setengah bagian seorang anak laki-laki. Oleh karena bagian yang ditetapkan di situ merupakan garis batas minimum berarti ketetapan itu bukan sukatan ukuran mati. Tetapi dapat diperbesar jumlahnya apabila suatu masa dan tempat, masyarakat Islam menghendaki dengan jalan memberi bagian yang sama antar lelaki dengan anak perempuan. Pengkajian tafsir ini dapat disepakati apabila masalah warisan dimasukkan dalam kategori "iba>dah mu'a>malah". Bukan bidang “ ibasdah at "ubu>diyah" yang melarang penggunaan nalar terlampau bebas. Menurutnya jika kita mencoba memahami hukum waris Islam dilihat dari pendekatan ilmu hukum umum. Warisan termasuk hukum perdata, rumusan dan substansinya pada hakikatnya bersifat "mengatur" bukan bersifat "imperatif" atau memaksa. Ajaran demikian, hampir bersamaan dengan sifat Ibadah Muamalah dalam ajaran Islam, yang memberikan gerak nalar berijtihad dengan ungkapan sabda Rasul "kamu lebih tahu mengenai urusan dunia".

3). Nurcholish Madjid,

Hal senada juga datang dari Nurchalis, saat heboh-hebohnya reaktualisasi ajaran agama yang dilontarkan Munawir Sjadzali. Menurut Nurchalish terkait polemik Aktualisasi Ajaran Islam yang digagas Mnawir Syadzali ini, Nurcholish menyampaikan dukungannya terhadap pemikiran Munawir ini dengan beranalogi dan mengkiaskannya dengan keberanian 
Ijtiha>d Umar bin Khatta`b, baginya perlu mempertimbangkan kemaslahatan atau kepentingan umum dalam usaha menangkap makna dan semangat berbagai ketentuan keagamaan. Pertimbangan itu terlebih lagi berlaku berkenaan dengan ketentuan agama yang tercakup dalam pengertian istilah "syari'ah" sebagai hal yang mengarah kepada sistem hukum dalam masyarakat (Madjid, 1988). Contoh klasik untuk tindakanan mempertimbangkan kepentingan umum dalam menangkap makna semangat agama itu ialah apa yang dilakukan oleh khalifah Umar ibn alKhatta>b RA, berkenaan dengan masalah tanah-tanah pertanian beserta garapangarapannya yang baru dibebaskan tentara Muslim di negeri Syam, Irak, Persi dan Mesir. Bukanlah berarti peniadaan ayat atau nas\}, melainkan justru berpegang teguh kepada nas\} itu dengan dalil-dalil berbagai nas\} lain mengikuti kemashlahatan umum.

4) Jalaluddin Rakhmat

Beliau menegaskan keberpihakanya kepada ide aktualisasi munawir ini dengan menyandarkannya dengan logika Umar yang telah melakukan penemuan hukum (ijtiha>d) yang dinilai mendatangkan kemashlahatan dimasa itu. Menurut Jalaludin paling tidak, ada lima pandangan tentang ijtihad Umar (Jalauddin, n.d.)

a) Ijtihad Umar tidak meninggalkan nash, apalagi mengganti atau menghapus ketentuannya. b) Ijtihad Umar memang meninggalkan z\}ahi>riyah nas\}, kaena ia berpegang pada ruhnya nas\},atau maqa>s\}id al-Ah\}ka>m alSyari>'ah.

c) Ijtihad Umar berkenaan dengan masalah-masalah yang qat\}'i hanya dibolehkan khusus untuk umar karena disebabkan juga karena kekurangan informasi terkait dalil .

d) Ijtihad Umar telah meninggalkan nas\{ yang s\}ari>h, tetapi tetap mendapatkan satu ganjaran pahala.

c. Kelompok Pendukung Gagasan Munawwir Dengan Syarat Revisi Terkait Porsi Warisan Anak Laki-Laki Dengan Anak Perempuan

1) K.H Ahmad Azhar Basyir

Menurutnya pengaturan hukum waris dalam al-Qur'an sudah diatur secara rinci, karena harta benda sangat mudah menimbulkan perselisihan karena secara naluri manusia sangat senang memperoleh kekayaan besar dan manusia seringkali serakah terhadap harta warisan. Untuk mengatasinya, Allah sendirilah yang membagi harta warisan secara teliti, menyeluruh dan utuh.

Ahmad Azhar Basyir memberikan solusi dan jalan tengah ketika seseorang hakim atau kondisi para ahli waris waktu itu menghadapi kasus khusus, orang tua boleh melakukan "s\}ulh\}u” atau perdamaian yang dilakukan ahli waris setelah masingmasing mengetahui haknya sesuai 
ketentuan hukum waris karena sematamata ingin menolong saudaranya yang susah.

\section{2) K.H. Ali Darokah}

K.H. Ali Darokah menjelaskan bahwa anak laki-laki tidak harus menerima dua kali lebih banyak dari anak perempuan. Menurutnya hukum faraid bukanlah semuanya dengan dasar dalil qat\}'i namun sebagiannya dengan dalil zanni> yang diambil dari ijtihardi dengan pertimbangan qiya>s atau maslah\}a〉t mursalah atau lain-lain seperti masalah $h\{$ ima $r i y a h$, masalah garawaìn dan masalah pembagian kakek dengan saudara laki-laki atau perempuan. KH Ali Darokah dalam memahami firman Allah "Li-dzakari mishlu ḩadzil unthsayainn" apabila seorang laki-laki sudah menghilangkan syarat "kelakilakiannya" sudah barang tentu, ketentuan hukum baginya pasti dapat berubah. Maksudnya disini adalah merelakan harta bagiannya yang telah ditentukan kepada waris lain dengan syarat, bahwa Is\}lash terjadi setelah masing-masing waris yang merelakan bagiannya, ia harus sudah mengetahui beberapa bagian yang menjadi miliknya, supaya jika ia rela, ya, benarbenar rela.

3) Syafruddin Prawiranegara

Surat An-Nisa ayat 11 itu menurutnya masuk kepada voluntary law ( hukum sukarela) yang artinya hukumnya baru berlaku, jika yang berkepentingan tidak mempergunakan alternatif (pilihan) lain yang tersedia. Kalau semua ahli waris sepakat secara sukarela, tanpa ada paksaan dari siapapun untuk membagi-bagi harta waris itu secara lain daripada yang ditetapkan dalam surat an-Nissa: 11, ini bukan merupakan "penyimpangan"dari ayat itu, tetapi sesuatu yang diizinkan Allah.

4) Amir Syarifuddin

Amir Syarifuddin menawarkan penyelesaian polemik ini, jika semua ahli waris sepakat secara sukarela, tanpa ada paksaan dari siapapun dengan melakukan takharrus sebagai hukum rukhshah dalam fikih. Dengan cara ini suatu kesulitan dalam memecahkan persoalan pembagian warisan dalam keadaan tertentu dapat diselesaikan.

\section{Analisa Metode Ijtihad dari beberapa} pendapat ketika formulasi Kompilasi Hukum Islam terkait Porsi Waris Anak 2:1.

Penulis melihat adanya dinamika perbedaan pendapat yang tajam antara tiga corak pemikiran hukum Islam di kalangan ulama dan cendikiawan muslim Indonesia, baik yang bercorak tekstual, pemikiran bercorak kontekstual seperti pemikiran dari para penggagas fikih Indonesia. Akhir dari polemik dan perdebatan pendapat yang tajam antara dua kelompok tersebut dimenangkan oleh pemikiran yang bercorak tekstual denga kuat dan gigihnya 
mempertahankan argumentasi yang mereka tawarkan. Hal ini dapat terlihat dengan dirumuskannya pasal 178 KHI.

Dilihat dari segi dalil yang dijadikan pedoman dirumuskannya pasal $178 \mathrm{KHI}$ termasuk kepada bentuk Ijtihâd bayânî. Dan jika dilihat dari segi bentuk karya ijtihadnya, termasuk kepada bentuk Ijtihad istinbâthî, yang berusaha menggali dan menemukan hukum dari dalil-dalil yang telah ditentukan yaitu berdasarkan pemahaman dari zhohir nash yang terdapat dalam surar an-Nissa' ayat 1l. Pemikiran hukum ini menilai hukum waris termasuk kategori ta'abbudi> dan bersifat ijbari>, sehingga mas\{lah\{at-nya hanya diketahui oleh Allah SWT dan mas\{lah\{at yang bertentangan dengan nash bukan mas\{lah\{at yang hakiki jadi kewarisan adat dan BW yang tidak sesuai dengan nas\} tidak bisa diterima.

Adanya 183 dalam KHI adalah usaha kelompok ketiga yang mencoba mengharmonisasikan pendapat sebelumnya. Kelompok ini mengakomodir hukum adat yang sudah lama dipraktekan di masyarakat, menjaga rasa keadilan yang dipahami oleh kelompok yang bercorak tekstual juga mempertimbangkan pendapat dari kelompok bercorak tekstual. Maka ketentuan penerapan hukum dalam pasal $178 \mathrm{KHI}$ tidak sesuatu yang final dan kaku, karena perlu dalam menerapkan pembagian waris antara anak laki-laki dan perempuan juga bisa menggunakan pasal 183 KHI jika telah memenuhi syarat dan ketentuan yang semestinya.

Kelompok ketiga ini mencoba meluruskan pemikiran Munawwir yang dinilai menerobos ketentuan zhohir nash, hal ini dianggap bentuk kesalahan dalam berijtihad. Kelompok ketiga mengajukan solusi untuk mencari jalan tengah dari dua pemikiran sebelumnya dengan menerima pendapat kelompok bercorak tekstual tetapi tetap mempertimbangkan realita praktek waris masyarakat dalam membagi sama rata antara anak laki-laki dengan anak perempuan, maka munculah ketentuan pasal 183 KHI, yang boleh diterapkan jika telah memenuhi syarat tertentu sehingga tidak termasuk meninggalkan nash.

Dilihat dari segi dalil yang dijadikan pedoman dirumuskannya pasal 183 KHI termasuk kepada bentuk Ijtihâd bayânî, dan jika dilihat dari segi bentuk karya ijtihadnya, maka dirumuskannya pasal 183 juga termasuk kepada bentuk Ijtihad istinbâthî, yang berusaha menggali dan menemukan hukum dari dalil-dalil yang telah ditentukan(Zahrah, n.d.) Dalam hal ini dalil yang digunakan dalam mencari solusi penyelesaian polemik kewarisan anak ini, dengn mengeluarkan istilah "is\}la>h" (perdamaian), berlandaskan kepada surat An-Nissa ayat 128: 
....Maka tidak mengapa bagi keduanya Mengadakan perdamaian yang sebenarbenarnya[358], dan perdamaian itu lebih baik (bagi mereka).

Dari kalimat Was\}sshulh\}u Khairu" dipahami akan bolehnya melakukan "sulh\}u" (istilah KH. Ahmad Azhar Basyir) atau "takhrijj" (istilah KH. Ali Darokah), yaitu para ahli waris sama-sama keluar dari ketentuan warisan sesuai fara'id, kemudian melakukan pembagian waris 1:l. hal ini dapat dilakukan setelah ahli waris masingmasing mengetahui dan merelakan haknya.

Penulis juga menyimpulkan bahwa pasal 183 KHI juga dibangun atas dasar kaidah istishlâh. (Zuhailî, 1986)Yaitu menjaga kemashlahatan dan keadilan dalam kasus khusus seperti keadaan anak perempuan di waktu pembagian hart warisan dalam keadaan susah sedangkan saudaranya yang laki-laki kaya dan berkecukupan atau karena anak laki-laki tersebut tidak melakukan tugas "kelakilakiannya" dalam hal member nafkah untuk keluarganya bahkan abai menjalankan fungsinya tersebut maka ketentuan waris ini bisa dibagi sama rata.

\section{E. Kesimpulan}

Dari pemaparan dan uraian dalam beberapa bab-bab yang telah diungkapkan sebelumnya, sampailah penulis pada kesimpulan bahwa pada awalnya perumusan KHI bersifat top-down karena digagas oleh elit politik pemegang kekuasaan eksekutif maupun yudikatif melalui pendekatan struktural. Namun tidak bisa dinafikan keterlibatan dan peran para ulama, cendikiawan dan praktisi hukum Islam. Polemik muncul ketika formulasi KHI disebabkan adanya tawaran pemikiran baru dari segelintir tokoh penggagas fikih Indonesia yang berbeda dengan pemahaman umum masyarakat yang sudah mapan, sehingga melahirkan tiga kelompok pemikiriran yaitu kelompok yang mendukung penuh, kelompok yang menolak dan kelompok yang mendukung pemikiran baru tersebut dengan syarat perlu adanya revisi. Perbedaan pendapat ketika formulsi KHI termasuk kategori ikhtilasf tanawwu' (variatif) dan al khilasf as sa’'igh al maqbu>l karena faktor terjadinya perbedaan tersebut disebabkan perbedaan dalam memahami dan menggunakan dalil dalam penyelesaian suatu hukum syara'.

Dinamika perbedaan pendapat dalam formulasi pasal waris, hibah dan wasiat KHI terlihat dengan adanya proses dialektika syariah dengan sosio-kultural di Indonesia juga disebabkan polemik penerapan teori maskah\}ah. Sehingga melahirkan tiga kelompok pemikiran hukum Islam, pertama, kelompok yang bercorak tekstual, kelompok ini menilai hukum waris termasuk kategori ta'abbudi dan ijbari , sehingga mas\{ah\{at-nya hanya diketahui oleh Allah SWT dan mas\{lah\{at 
yang bertentangan dengan nash bukan mas\{lah\{at yang hakiki. Kewarisan adat dan BW yang tidak sesuai dengan nas\} tidak bisa diterima. Kedua, kelompok bercorak kontekstul, dalam merumuskan hukum kewarisan KHI corak kelompok ini menerima hukum adat dan BW, karena hukum Islam haruslah diderivasikan dari karakteristik masyarakat Indonesia. Kelompok ini mencoba menawarkan tafsir baru dalam memahami nas\} qat\}'i Ketiga, kelompok pemikiran yang mengambil sikap harmonisasi (wasatîyah), yang tidak terlalu tekstual dan tidak terlalu bebas. Waris termasuk kategori ibadah mu'amalat yang mesti terbuka dan inklusif menerima pembaharuan dengan tetap berpegang pada nas\} dan kemashlahatan umum seperti hukum Islam harus tunduk dengan hukum yang lebih besar (hukum nasional) dengan mempertimbangkan hirarki hukum yang berlaku di Indonesia. Dan jika dilihat dari segi metode ijtihadnya, beberapa pasal terkait waris, hibah dan wasiat dalam KHI umumnya melakukan penggabungan antara ijtihad selektif (Ijtihad intiqo' 'ì) dengan ijtihad kreatif (insya’’i).

\section{Daftar Pustaka}

Bakar, Al-Yasa, abu, Ahli Waris Sepertalian Darah: kajian perbandingan terhadap penalaran Hazairin dan Penalaran Fikih Mazhab Jakarta: INIS, 1998.
Basyir, Ahmad Azhar "Corak lokal dalam Hukum Positif Islam di Indonesia (Sebuah Tinjauan Filosofis)", Mimbar Hukum,No.13, Th.IV, 1994.

Basri, Cik Hasan dkk, Kompilasi Hukum Islam dalam Sistem Hukum Nasional, Jakarta:Logos wacana Ilmu, 1999.

Bruinessen, Martin NU Tradisi, Relasi-relasi Kuasa Pencarian Wacana Baru Yogyakarta: LKIS. 1994.

Buthi, Said Ramadhan al-, Alla Mazhabiyah Akhtharu Bid'ah Tuhaddidu al-Syari'ah al -islamiyah, Pent Anas Thohir Samsuddin, Surabaya: Ibnu Ilmu, 1981.

Burhan, Bungin, Metodologi Penelitian Kualitatif, Jakarta: Rajawali Pers, 2011.

Djamil, Faturrahman, Metode Ijtihad Majlis Tarjih Muhammadiyah, Jakarta: Logos Publising Haouse, 1995.

Dirjen Binbaga Islam, Kompilasi Hukum Islam, (Jakarta: Depertemen Agama R.I, 1991.

Dudung, Abdurrahman, Metode Penelitian Sejarah, Jakarta: Logos Wacana Ilmu, 1999.

Falusi, Mas'ud bin Musa Madrasah alMutakallimin wa Manhajuhu fi Dirasati Us\}uli Fiqh, Maktabah al-Rusy, Riyad, 2004.

Feener, R. Michael Muslim Legal Thought In Modern Indonesia, New York: Cambridge University Press, 2007.

Friedman, Lawrence M., Sistem Hukum Perspektif ilmu Sosial, (Penterjemah M. Khozim, Bandung: Nusa Media, 2009.

Fuad, Mahsun Hukum Islam Indonesia: Dari Nalar Partisipatoris hingga Emansipatoris , Yogyakarta: LKiS, 2005. 
Ghazali, Abu Hamid, al-Mustahfa fi Ilmu alUs\}ul, Beirut: Dar-Kutub alIlmiyah, 1983.

Ghazali,Moqsit,dalamhttp://islamlib.com/i $\mathrm{d}$ /artikel/hukumwaris-dalamsuatu-konteks, diunduh pada 19 September 2012.

Habiburrahman, Rekonstruksi Hukum Kewarisan Islam di Indonesia, Jakarta: Kencana, 2011.

Harahab, Abdul Ghofur Yulkarnain, Dinamika Hukum Islam Dan Perkembangannya Di Indonesia, Yogjakarta: Kreasi Total Media, 2008.

Harahap, M. Yahya, Mempositifkan Abstraksi Hukum Islam, Jakarta: PT. Logos Wacana Ilmu, 1999.

Hasballah,Ali, Ushul at-Tasyri al-Islami, Mesir : Dar al-Ma'arif, 1986.

Hidayatullah, Kajian Islam Tentang Berbagai Masalah Kontemporer. Jakarta: Hikmah Syahid Indah, 1988

Himpunan Putusan Tarjih, Yogyakarta: PP Muhammadiyah. Jogjakarta, 1992.

Hooker, M.B. Undang-Undang Islam di Asia Tenggara, terj. Rohani Abdul Rahim dkk. Kuala Lumpur: Dewan Bahasa dan Pustaka Kementerian Pendidikan Malaysia, 1992

Haroen,Nasrun ,Ijtihad Ibn al-2ayyim atJauziyah dalam Konteks Perubahan Sosial, DisertasiDoktor, Jakarta, 1996.

Huberman, Matthew B.Miles \& A. Michel Analisa data Kualitatif, Terj Tjetjep Rohandi Rohidi, Jakarta : Universitas Indonesia, 1992

Husein, Amin Nasution, Hukum Kewarisan, Suatu Analisis Komparatif Pemikiran Mujtahiddan Kompilasi Hukum Islam, Jakarta: Rajawali Pers, 2012.
Husnan, Ahmad, Keputusan Al-Qur'a>n di Gugat , Bangil: Yayasan alMuslimun, 1991.

Ibrahim, Muhammad Ismail Mu'jamAlfazhwa at-A'lam al-Quraniyah, Kairo: Dar alFikr al-'Arabi, [t.th]).

Ibrahim muh\}ammad al-Jama>l, Fiqh Muslim 'ala al-Maza>hib al-Arba'ah, Jilid 2, ,Beirut: Da>r al-Jilid.

Ibrahim, Nana Sudjana Penelitian dan Penilaian Pendidikan, Bandung: Sinar Baru, 1984.

Idris, Mahsyar Verifikasi dan Catatan Terhadap Kitab Himpunn Putusan Tarjih Muhammadiyah,Pare-pare: Lembaga Penerbitan Muhammadiyah ParePare, 2010.

Inkeles, Alex, The Modern Man, Modernization:The Dynamic of Growth, Voice of America Lecturer,1966.

Jafizham , T., Persentuhan Hukum di Indonesia dengan Hukum Perkawinan Islam, Medan: Percetakan Mustika, 1977.

Jawar, Ahmad 'Abd, Usul 'Ilm al-Mawaritsh (Beirut:Dar al-Kutubal-Ilmiyah, 1998.

Jizani, Muhammad bin Husain al Ma'alim, Us\}ul al Fiqh , Jeddah: Dar Ibn al Jauzi, 1998.

Jum'ah, Ali, Ilmu Us\}ul lil Fiqh wa 'Alaqatuhu bi'I Falsafah al-islamiyah, Cairo, AlFikry Al-Islami,1996.

Jurnal al-Ahkam, "Dinamika Pemikiran Fikih Mazhab Indonesia" (Perspektif

Ka'bah, Rifyal' Penegakan Syari'at Islam Di Indonesia, Jakarta, Rifyal Ka'bah Foundation, 2016.

Madjid, Nurcholis dkk, Fiqih Lintas Agama: Membangun Masyarakat InklusifPluralis, (Editor: Mun'im A. Sirry.), Jakarta: Paramadina, 2004. 
Mah\{alli, Jala>l al-Di>n, Syarh Minha>j alT\{a>libi>n,3 (Kairo: Da>r Ih\{ya alKutub al-'Arabi’,tt.

Mahfud, Moh MD, Politik Hukum di Indonesia, Jakarta: PT Raja Grafindo Persada, 2009 Edisi Revisi.

Mahfuzh,Sahal Nuansa, Fiqih Sosial, Yogyakarta: LKiS, 1994.

Mahmassani, Sobhi Filsafat Hukum dalam Islam, terjemahan Ahmad Sidjono (Bandung: PT. Al-Ma'arif, 1981.

Malik, al-Mudawanah al-Kubra>, Mesir: alSa'a>dah: t.th.

Manan, Abdul, Masalah Hukum Perdata Islam di Indonesia,(Jakarta: Prenada Media Group, 2008.

Mantja, W., Etnografi Desain Penelitian Kualitatif dan Manajemen
Pendidikan, Malang: Winaka Media, 2003.

Marzuki, Metodologi Riset, Yogyakarta: BPFE-UII, 1991.

Maraghi, Ahmad Musthafa, Tafsir alMaraghi, [t.t]: Dar al-Fikr, 1974.2004.

Martadi.E, Kompilasi Hukum Islam sebagai Hukum Terapan di Pengadilan Agama. dalam Mimbar Hukum No. 24 thn VII, Jakarta: PT. Internusa, 1996.

Nurlaelawati, Euis, Jurnal Ilmu Syari'ah dan Hukum, Hukum Keluarga Islam ala Negara Vol. 50, No. 1, Juni 2016.

Praja, Juhaya S., Filsafat Hukum Islam, Bandung: Pusat Penerbitan Universitas Islam, 1995. 